\title{
Desulfuromonas svalbardensis sp. nov. and Desulfuromusa ferrireducens sp. nov., psychrophilic, Fe(III)-reducing bacteria isolated from Arctic sediments, Svalbard
}

Correspondence Verona Vandieken vvandiek@mpi-bremen.de

\author{
Verona Vandieken, Marc Mußmann, Helge Niemann \\ and Bo Barker Jørgensen
}

Max-Planck-Institute for Marine Microbiology, Celsiusstrasse 1, 28359 Bremen, Germany
The genus Desulfuromonas was first described by Pfennig \& Biebl (1976), who isolated the marine species Desulfuromonas acetoxidans, which reduces elemental sulfur with acetate. The genus contains four further species, which had been isolated with reduction of iron, sulfur or tetrachloroethene from marine and freshwater sediments: Desulfuromonas palmitatis (Coates et al., 1995), Desulfuromonas acetexigens (Finster et al., 1994), Desulfuromonas thiophila (Finster et al., 1997) and Desulfuromonas chloroethenica (Krumholz, 1997; Krumholz et al., 1996). The genus Desulfuromusa is represented by three species, Desulfuromusa bakii, Desulfuromusa kysingii and Desulfuromusa succinoxidans, isolated by elemental sulfur reduction (Liesack \& Finster, 1994). Together with the genera Pelobacter, Malonomonas and Geobacter, Desulfuromusa and Desulfuromonas form the family Geobacteraceae Holmes et al. 2004, a monophyletic group within the Deltaproteobacteria (Holmes et al., 2004a; Lonergan et al., 1996). An important characteristic of species within this group is the ability to reduce $\mathrm{Fe}(\mathrm{III})$ and/ or elemental sulfur. Additionally, some species grow by fermentation or syntrophically (Cord-Ruwisch et al., 1998; Schink, 1984; Schink \& Pfennig, 1982; Schink \& Stieb, 1983).

The GenBank/EMBL/DDBJ accession numbers for the 16S rRNA gene sequences of strains $112^{\top}, 49,60,103$ and $102^{\top}$ are AY835388-AY835392, respectively.
Due to the variety of metabolic pathways performed by isolated species of the Geobacteraceae, the in situ activity of this group remains unclear, since several constituents in freshwater and marine sediments can usually be utilized by these bacteria.

Strains were obtained from enrichment cultures inoculated with surface sediments of two fjords along the west coast of Svalbard with bottom water temperatures of $2-3{ }^{\circ} \mathrm{C}$. Strains $49,60,102^{\mathrm{T}}$ and 103 originated from Tempelfjorden, Station $\mathrm{CD}\left(78^{\circ} 25 \cdot 267^{\prime} \mathrm{N} 17^{\circ} 08 \cdot 277^{\prime} \mathrm{E}\right.$; water depth $\left.64 \mathrm{~m}\right)$ and strain $112^{\mathrm{T}}$ from Smeerenburgfjorden, Station J $\left(79^{\circ} 42 \cdot 006^{\prime}\right.$ $\mathrm{N} 11^{\circ} 05 \cdot 199^{\prime} \mathrm{E}$; water depth $212 \mathrm{~m}$ ). Enrichment and isolation were performed in artificial sea-water medium (Widdel \& Bak, 1992) with a reduced $\mathrm{MgSO}_{4} .7 \mathrm{H}_{2} \mathrm{O}$ concentration of $0.4 \mathrm{mM}$ to avoid growth of sulfate-reducing bacteria. Acetate $(20 \mathrm{mM})$ and synthetically produced poorly crystalline iron oxide $(\sim 30 \mathrm{mM})$ (Lovley, 2000) were added for enrichments at $10^{\circ} \mathrm{C}$. For the isolation in deep-agar dilution technique (Isaksen \& Teske, 1996), iron oxide was replaced with soluble ferric citrate $(\sim 30 \mathrm{mM})$. For the determination of alternative substrates and salt, $\mathrm{pH}$ and vitamin requirements, growth medium with a lower salt concentration was used (salt-water medium) (Widdel \& Bak, 1992). All physiological tests were performed in duplicate at $10^{\circ} \mathrm{C}$. Cultures growing with alternative substrates 
were transferred into fresh test medium for verification. Temperature tolerance of the strains was determined in an aluminium temperature-gradient block at 13 different temperatures between -2 and $30^{\circ} \mathrm{C}$ (Sagemann et al., 1998). Salt requirements were determined in media with 12 different $\mathrm{NaCl}$ concentrations between 0.05 and $5 \%(\mathrm{w} / \mathrm{v})$ and 10 different $\mathrm{MgCl}_{2} \cdot 6 \mathrm{H}_{2} \mathrm{O}$ concentrations between 0.02 and $3.6 \%(\mathrm{w} / \mathrm{v})$. The $\mathrm{pH}$ optima of the strains were determined in media with 12 different $\mathrm{pH}$ values (in triplicate) that covered a range from $\mathrm{pH} 5 \cdot 5$ to $8 \cdot 3$. For all tests, growth was monitored spectrophotometrically (Shimadzu UV 1202) by measuring the OD at $580 \mathrm{~nm}$ for cells grown on fumarate/ acetate and by measuring $\mathrm{Fe}^{2+}$ accumulation (Stookey, 1970) for cells grown on ferric citrate/acetate. Reduction of ferric citrate was also tested in media with $\mathrm{FeCl}_{2} \cdot 4 \mathrm{H}_{2} \mathrm{O}$ (2-3 mM end concentration) or cysteine ( $1 \mathrm{mM}$ end concentration) as reducing agents instead of sulfide.

Malonomonas rubra DSM 5091 ${ }^{\mathrm{T}}$, obtained from the Deutsche Sammlung von Mikroorganismen und Zellkulturen (DSMZ, Braunschweig, Germany), was grown in salt-water medium with malonate as substrate. To test the ability of cells to grow by $\mathrm{S}^{0}, \mathrm{Fe}(\mathrm{III})$ or $\mathrm{Mn}(\mathrm{IV})$ reduction, malonate was replaced with ferric citrate, poorly crystalline iron oxide, manganese oxide or $\mathrm{S}^{0}$ as electron acceptor and acetate as electron donor.

Fatty acids were analysed by GC and GC-MS (Elvert et al., 2003). Lipoquinones, the $\mathrm{G}+\mathrm{C}$ content of genomic DNA and DNA-DNA hybridization were determined at the DSMZ.

PCR amplification of 16S rRNA genes was performed with the primers $8 \mathrm{~F}$ and $1492 \mathrm{R}$ and $\mathrm{PCR}$ products were amplified for sequence analysis with primers $8 \mathrm{~F}, 341 \mathrm{~F}, 518 \mathrm{~F}, 534 \mathrm{R}$, 1099F and 1492R (Buchholz-Cleven et al., 1997). The ARB program (Ludwig et al., 2004) was used for phylogenetic analysis.

Purity of cultures of strains $49,60,103,112^{\mathrm{T}}$ and $102^{\mathrm{T}}$ was checked microscopically and by inoculating the cultures into media with yeast extract, casein, glucose or fructose. Strains $49,60,103$ and $112^{\mathrm{T}}$ were all phylogenetically closely related (99.4-99.7\% 16S rRNA gene sequence similarity). The strains were tested for growth with a selection of environmentally important electron acceptors and donors and showed similar substrate spectra (data not shown). Furthermore, the strains all revealed similar optimum growth temperatures around $15^{\circ} \mathrm{C}$ and growth at $0{ }^{\circ} \mathrm{C}$ (data not shown). Due to the similarities of strains $49,60,103$ and $112^{\mathrm{T}}$, strain $112^{\mathrm{T}}$ was selected for further detailed characterization. Strain $102^{\mathrm{T}}$ was also characterized in detail.

Cells of strains $112^{\mathrm{T}}$ and $102^{\mathrm{T}}$ grew as thin rods (Fig. 1). Cells of strain $112^{\mathrm{T}}$ were $0 \cdot 7 \times 2-3 \cdot 5 \mu \mathrm{m}$ and those of strain $102^{\mathrm{T}}$ were $0 \cdot 7-1 \times 3-5 \mu \mathrm{m}$ in size. Cells of the latter strain formed clumps in liquid culture. Both strains stained Gramnegative and were non-spore-forming and motile. Electron
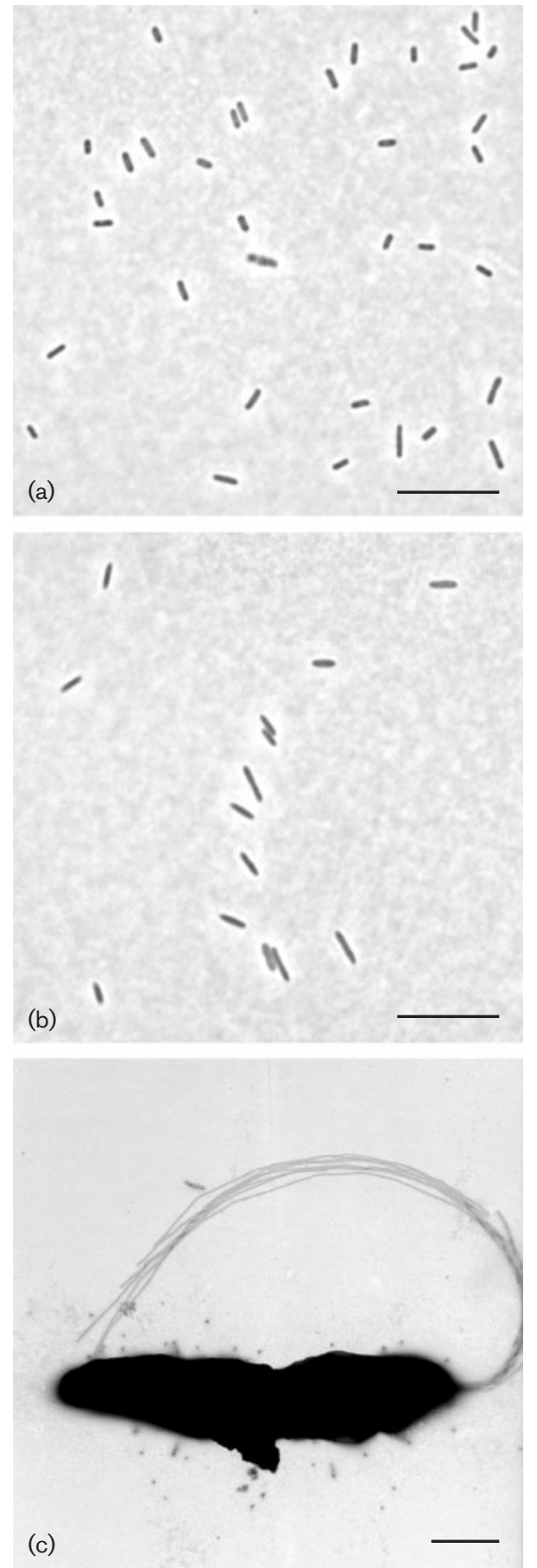

Fig. 1. (a, b) Phase-contrast micrographs of Desulfuromonas svalbardensis $112^{\top}$ (a) and Desulfuromusa ferrireducens $102^{\top}$ (b). (c) Electron micrograph of Desulfuromusa ferrireducens $102^{\top}$, showing the rod shape and the monopolar lophotrichous flagellation. Bars, $10 \mu \mathrm{m}(\mathrm{a}, \mathrm{b})$ and $1 \mu \mathrm{m}(\mathrm{c})$.

microscopy (Zeiss EM $10 \mathrm{~A}$; conducted at the UFT, University of Bremen) revealed peritrichous flagellation for strain $112^{\mathrm{T}}$ and monopolar lophotrichous flagellation for strain $102^{\mathrm{T}}$ (Fig. 1c). 
Both strains grew at $-2{ }^{\circ} \mathrm{C}$, the freezing point of sea water. Strain $112^{\mathrm{T}}$ grew fastest at $14^{\circ} \mathrm{C}$ and did not grow above $20{ }^{\circ} \mathrm{C}$. The temperature optimum of strain $102^{\mathrm{T}}$ was between 14 and $17^{\circ} \mathrm{C}$ and the maximum temperature was $23^{\circ} \mathrm{C}$. According to their temperature ranges for growth, both strains were defined as psychrophiles. Strain $112^{\mathrm{T}}$ had an optimum for $\mathrm{NaCl}$ at $2 \cdot 6 \%$, growing between 0.7 and $4 \cdot 5 \%$. The optimum concentration for $\mathrm{MgCl}_{2} \cdot 6 \mathrm{H}_{2} \mathrm{O}$ was between 0.02 and $0.8 \%$, and growth was inhibited at concentrations above $1.9 \%$. For strain $102^{\mathrm{T}}$, the optimum for $\mathrm{NaCl}$ was $2 \cdot 6-4 \%$, with growth ranging from $1 \cdot 5$ to $4 \cdot 5 \%$. The strain grew equally well over the range of 0.4 to $3.6 \%$ $\mathrm{MgCl}_{2} \cdot 6 \mathrm{H}_{2} \mathrm{O}$. Thus, both strains grew at sea-water concentrations of $\mathrm{NaCl}$ and $\mathrm{MgCl}_{2} \cdot 6 \mathrm{H}_{2} \mathrm{O}$, which are $2.5 \%$ for $\mathrm{NaCl}$ and $1 \cdot 1 \%$ for $\mathrm{MgCl}_{2} \cdot 6 \mathrm{H}_{2} \mathrm{O}$. Strain $112^{\mathrm{T}}$ grew at $\mathrm{pH} 6 \cdot 5-7 \cdot 5$, with an optimum at $\mathrm{pH} 7 \cdot 3$. Strain $102^{\mathrm{T}}$ showed a similar growth range of $\mathrm{pH} 6 \cdot 5-7 \cdot 9$ and an optimum at $\mathrm{pH} 7 \cdot 0-7 \cdot 3$.

Strain $112^{\mathrm{T}}$ grew in the presence of ferric citrate with acetate, propionate, pyruvate, ethanol, propanol, butanol, proline and choline chloride as electron donors and strain $102^{\mathrm{T}}$ with acetate, lactate, formate, $\mathrm{H}_{2}\left(\mathrm{H}_{2} / \mathrm{CO}_{2} ; 80: 20\right.$, v/v), succinate, pyruvate, fumarate, ethanol, propanol, butanol and proline. Electron donors not used by either strain were butyrate, hexanoate, malate, succinate, citrate, fructose, glucose, glycerol, glycine, glutarate, alanine, serine, proline, betaine, sorbitol, nicotinate, yeast extract and casein; substrates not used by strain $112^{\mathrm{T}}$ were lactate, formate, fumarate, succinate and $\mathrm{H}_{2}$, and strain $102^{\mathrm{T}}$ did not use propionate or choline chloride. Both strains grew by reduction of $\mathrm{Fe}(\mathrm{III})$ compounds (ferric citrate and iron oxide tested) and fumarate in the presence of acetate. Additionally, the strains slowly reduced elemental sulfur and manganese oxide. Neither strain reduced sulfate, thiosulfate, sulfite, nitrate, nitrite, oxygen or malate. Ferric citrate was also reduced in media with $\mathrm{FeCl}_{2}$ or cysteine as reducing agents instead of sulfide. No reduction of Fe(III) in the presence of oxygen was observed for either strain. Disproportionation of sulfur or thiosulfate was not observed. Both strains grew with fumarate as the sole substrate, but not with lactate, malate, malonate, pyruvate, glucose or fructose. The major end product of fumarate disproportionation was succinate. Strain $102^{\mathrm{T}}$ did not require vitamins for growth, whereas strain $112^{\mathrm{T}}$ required biotin.

The phospholipid-derived ester-linked fatty acid composition of strains $112^{\mathrm{T}}$ and $102^{\mathrm{T}}$ is listed in Table $1 . \mathrm{C}_{16: 1} \omega 7 c$ and $\mathrm{C}_{16: 0}$ were dominant as fatty acids in both strains, similar to the fatty acid composition of Geobacter metallireducens (Lovley et al., 1993). Cells of strain $112^{\mathrm{T}}$ contained MK-8 as the major menaquinone and traces of MK-9 (2\%); cells of strain $102^{\mathrm{T}}$ contained only MK-8. The DNA G $+\mathrm{C}$ contents were $50 \cdot 1 \mathrm{~mol} \%$ for strain $112^{\mathrm{T}}$ and $52 \cdot 3 \mathrm{~mol} \%$ for strain $102^{\mathrm{T}}$.

Comparative analysis of the 16S rRNA gene sequences showed that both strains belong to the Deltaproteobacteria (Fig. 2). Strain $112^{\mathrm{T}}$ was related to Desulfuromonas
Table 1. Fatty acid abundances of strains $112^{\top}$ and $102^{\top}$

Values are proportions of total fatty acids. tr, Trace $(<0 \cdot 01)$. Major components are shown in bold.

\begin{tabular}{|llc|}
\hline Fatty acid & $\mathbf{1 1 2}^{\mathrm{T}}$ & $\mathbf{1 0 2}^{\mathrm{T}}$ \\
\hline $\mathrm{C}_{13: 0}$ & $0 \cdot 01$ & $0 \cdot 01$ \\
$\mathrm{i}-\mathrm{C}_{14: 0}$ & 0 & $\operatorname{tr}$ \\
$\mathrm{C}_{14: 0}$ & $0 \cdot 07$ & $0 \cdot 07$ \\
$\mathrm{i}-\mathrm{C}_{15: 0}$ & $0 \cdot 02$ & 0 \\
ai- $\mathrm{C}_{15: 0}$ & 0 & $0 \cdot 01$ \\
$\mathrm{C}_{15: 0}$ & $0 \cdot 01$ & $0 \cdot 01$ \\
$\mathrm{C}_{16: 1} \omega 9 c$ & $0 \cdot 01$ & $0 \cdot 01$ \\
$\mathrm{C}_{16: 1} \omega 7 c$ & $\mathbf{0} \cdot \mathbf{3 5}$ & $\mathbf{0} \cdot 39$ \\
$\mathrm{C}_{16: 1} \omega 7 t$ & 0 & $0 \cdot 02$ \\
$\mathrm{C}_{16: 1} \omega 5 c$ & $0 \cdot 04$ & $0 \cdot 01$ \\
$\mathrm{C}_{16: 0}$ & $\mathbf{0} \cdot \mathbf{4 3}$ & $\mathbf{0} \cdot 36$ \\
$10-\mathrm{Me} \mathrm{C}_{16: 0}$ & 0 & $\operatorname{tr}$ \\
$\mathrm{i}-\mathrm{C}_{17: 0}$ & $\operatorname{tr}$ & $\operatorname{tr}$ \\
ai- $\mathrm{C}_{17: 0}$ & $\operatorname{tr}$ & $\operatorname{tr}$ \\
$\mathrm{C}_{17: 0}$ & 0 & $0 \cdot 01$ \\
$\mathrm{C}_{18: 2}$ & 0 & $0 \cdot 02$ \\
$\mathrm{C}_{18: 1} \omega 9$ & $0 \cdot 01$ & $0 \cdot 02$ \\
$\mathrm{C}_{18: 1} \omega 7$ & $0 \cdot 01$ & $0 \cdot 01$ \\
$\mathrm{C}_{18: 1} \omega 5$ & $\operatorname{tr}$ & 0 \\
$\mathrm{C}_{18: 0}$ & $0 \cdot 02$ & $0 \cdot 06$ \\
& & \\
\hline
\end{tabular}

acetoxidans (97.0 \% 16S rRNA gene sequence similarity), Desulfuromonas thiophila $\mathrm{NZ}_{2} 7^{\mathrm{T}}(95 \cdot 5 \%)$, Pelobacter venetianus $\left(93.7 \%\right.$ ) and Desulfuromonas chloroethenica $\mathrm{TT}^{4} \mathrm{~B}^{\mathrm{T}}$ (93.1\%). Species of the genus Desulfuromonas were isolated by reduction of elemental sulfur [Desulfuromonas acetoxidans (Pfennig \& Biebl, 1976), Desulfuromonas acetexigens (Finster et al., 1994) and Desulfuromonas thiophila (Finster et al., 1997)], tetrachloroethene [Desulfuromonas chloroethenica (Krumholz, 1997; Krumholz et al., 1996) and 'Desulfuromonas michiganensis' (Sung et al., 2003)] or Fe(III) compounds [Desulfuromonas palmitatis (Coates et al., 1995)]. However, all species of this genus were able to reduce iron compounds and sulfur (Table 2). Strain $112^{\mathrm{T}}$ was most closely related to the marine species Desulfuromonas acetoxidans, which, similarly to strain $112^{\mathrm{T}}$, was able to reduce elemental sulfur, $\mathrm{Fe}(\mathrm{III})$ and $\mathrm{Mn}$ (IV) (Pfennig \& Biebl, 1976; Roden \& Lovley, 1993). The two strains differed mainly in their temperature tolerance, with Desulfuromonas acetoxidans being mesophilic, growing between 25 and $35^{\circ} \mathrm{C}$, and strain $112^{\mathrm{T}}$ being psychrophilic, growing between -2 and $20^{\circ} \mathrm{C}$. Physiological differences between the two strains were the ability of strain $112^{\mathrm{T}}$ to oxidize propionate and to grow by disproportionation of fumarate and its inability to reduce malate (Table 2 ). DNA-DNA hybridization determined $22 \cdot 7 \%$ relatedness between strain $112^{\mathrm{T}}$ and Desulfuromonas acetoxidans DSM $684^{\mathrm{T}}$. Therefore, we propose the description of strain $112^{\mathrm{T}}$ as the type strain of a novel species, Desulfuromonas svalbardensis sp. nov.

The closest relatives of strain $102^{\mathrm{T}}$ were Malonomonas rubra Gra Mal $1^{\mathrm{T}}$ (96.3\% 16S rRNA gene sequence similarity), 


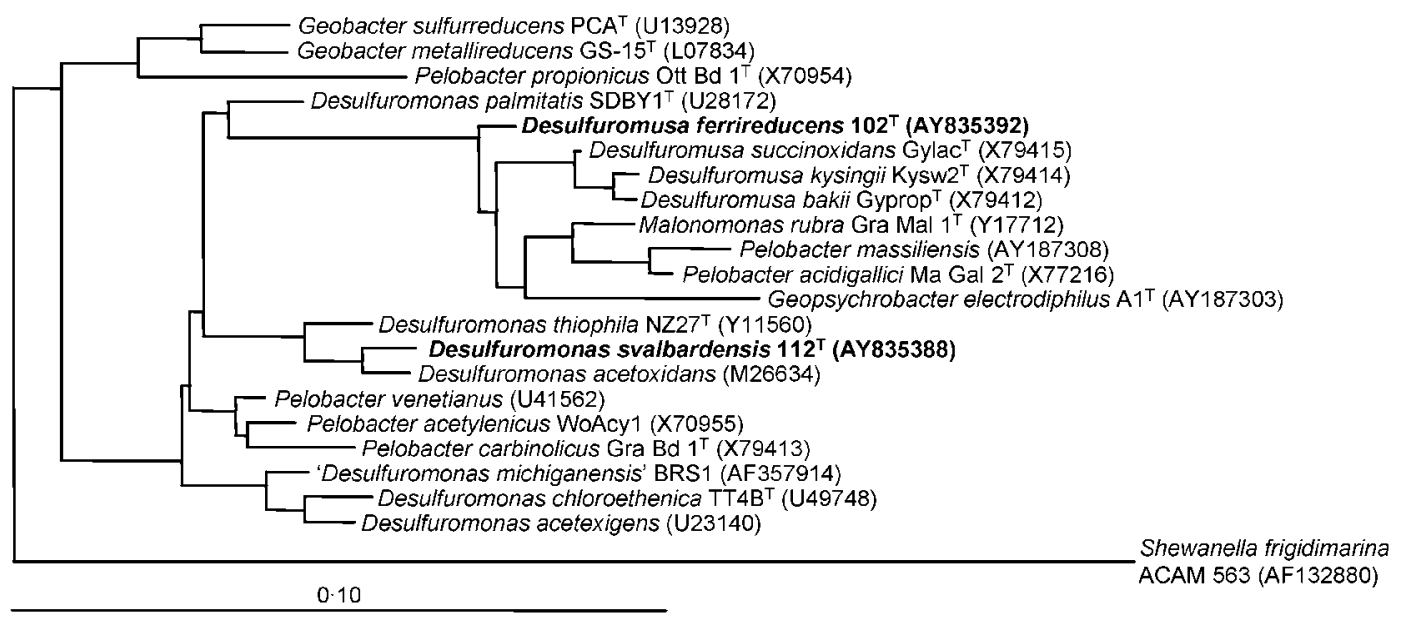

Fig. 2. Phylogenetic tree of $16 \mathrm{~S}$ rRNA gene sequences based on maximum-likelihood methods with a $50 \%$ filter for Deltaproteobacteria, showing the position of Desulfuromusa ferrireducens $102^{\top}$ and Desulfuromonas svalbardensis $112^{\top}$. Bar, $10 \%$ estimated sequence divergence.

Desulfuromusa succinoxidans Gylac $^{\mathrm{T}}$ (95.9\%), Desulfuromusa kysingii $\mathrm{Kysw}^{\mathrm{T}}(95.5 \%)$ and Desulfuromusa bakii Gyprop $^{\mathrm{T}}(95 \cdot 4 \%)$. Malonomonas rubra is so far the only described species of this genus, and the genus was established because of the ability of this species to grow by fermentation of malonate (Dehning \& Schink, 1989), but cells did not grow by anaerobic respiration (Kolb et al., 1998). The ability of Malonomonas rubra to reduce iron compounds was described recently (Holmes et al., 2004a), and these authors suggested that Malonomonas rubra should be renamed as a member of the genus Desulfuromusa. This is supported by our results, as Malonomonas rubra DSM 5091 ${ }^{\mathrm{T}}$ reduced ferric citrate, iron oxide, elemental sulfur and manganese oxide with acetate as electron donor (Table 3). Therefore, we propose strain $102^{\mathrm{T}}$ as the type strain of a novel species of the genus Desulfuromusa, Desulfuromusa ferrireducens sp. nov. The newly isolated strain $102^{\mathrm{T}}$ was psychrophilic, growing between -2 and $23{ }^{\circ} \mathrm{C}$, whereas the other Desulfuromusa species do not grow below $4{ }^{\circ} \mathrm{C}$ and their optimum temperatures for growth are $\geqslant 25^{\circ} \mathrm{C}$ (Finster \& Bak, 1993; Liesack \& Finster, 1994). The psychrotolerant species Geopsychrobacter electrodiphilus is closely related to species of Desulfuromusa and Malonomonas rubra, but represents a unique phylogenetic cluster (Holmes et al., 2004b). Species of Desulfuromusa, Malonomonas rubra, strain $102^{\mathrm{T}}$ and Geopsychrobacter electrodiphilus share the

Table 2. Major characteristics of species of the genus Desulfuromonas and strain $112^{\top}$

Reference species: 1, Desulfuromonas acetoxidans; 2, Desulfuromonas acetexigens; 3, Desulfuromonas thiophila; 4, Desulfuromonas chloroethenica; 5, Desulfuromonas palmitatis; 6, 'Desulfuromonas michiganensis'. Data for reference species were taken from Pfennig \& Biebl (1976), Finster et al. (1994, 1997), Coates et al. (1995), Krumholz (1997) and Sung et al. (2003). ND, Not determined; +, substrate used for growth; -, substrate not used for growth; $(+)$, substrate reduced but no growth observed. All taxa use sulfur as an electron acceptor. Not all electron donors and acceptors used by the species are listed in this table.

\begin{tabular}{|c|c|c|c|c|c|c|c|}
\hline Characteristic & Strain $112^{\mathrm{T}}$ & 1 & 2 & 3 & 4 & 5 & 6 \\
\hline Temperature optimum $\left({ }^{\circ} \mathrm{C}\right)$ & 14 & 30 & 30 & $26-30$ & $21-31$ & 40 & 25 \\
\hline Temperature range $\left({ }^{\circ} \mathrm{C}\right)$ & -2 to 20 & $25-35$ & $\mathrm{ND}$ & $10-40$ & $21-31$ & ND & $5-45$ \\
\hline \multicolumn{8}{|l|}{ Electron donors } \\
\hline Propionate & + & - & - & - & ND & - & - \\
\hline \multicolumn{8}{|l|}{ Electron acceptors } \\
\hline $\mathrm{Fe}(\mathrm{III})$ compounds & + & + & $\mathrm{ND}$ & $(+)$ & + & + & + \\
\hline $\operatorname{Mn}(\mathrm{IV})$ oxide & + & + & $\mathrm{ND}$ & $\mathrm{ND}$ & ND & + & ND \\
\hline Fumarate & + & + & + & - & + & + & + \\
\hline Malate & - & + & + & - & ND & - & + \\
\hline Disproportionation of fumarate & + & - & $\mathrm{ND}$ & - & ND & $\mathrm{ND}$ & + \\
\hline
\end{tabular}


Table 3. Major characteristics of species of the genus Desulfuromusa, Malonomonas rubra, Geopsychrobacter electrodiphilus and strain $102^{\top}$

Reference species: 1, Desulfuromusa succinoxidans; 2, Desulfuromusa kysingii; 3, Desulfuromusa bakii; 4, Malonomonas rubra; 5, Geopsychrobacter electrodiphilus. Data for reference species were taken from Liesack \& Finster (1994), Dehning \& Schink (1989) and Holmes et al. (2004b). ND, Not determined; +, substrate used for growth, -, substrate not used for growth. All taxa use elemental sulfur as an electron acceptor. Not all electron donors and acceptors used by the species are listed in this table.

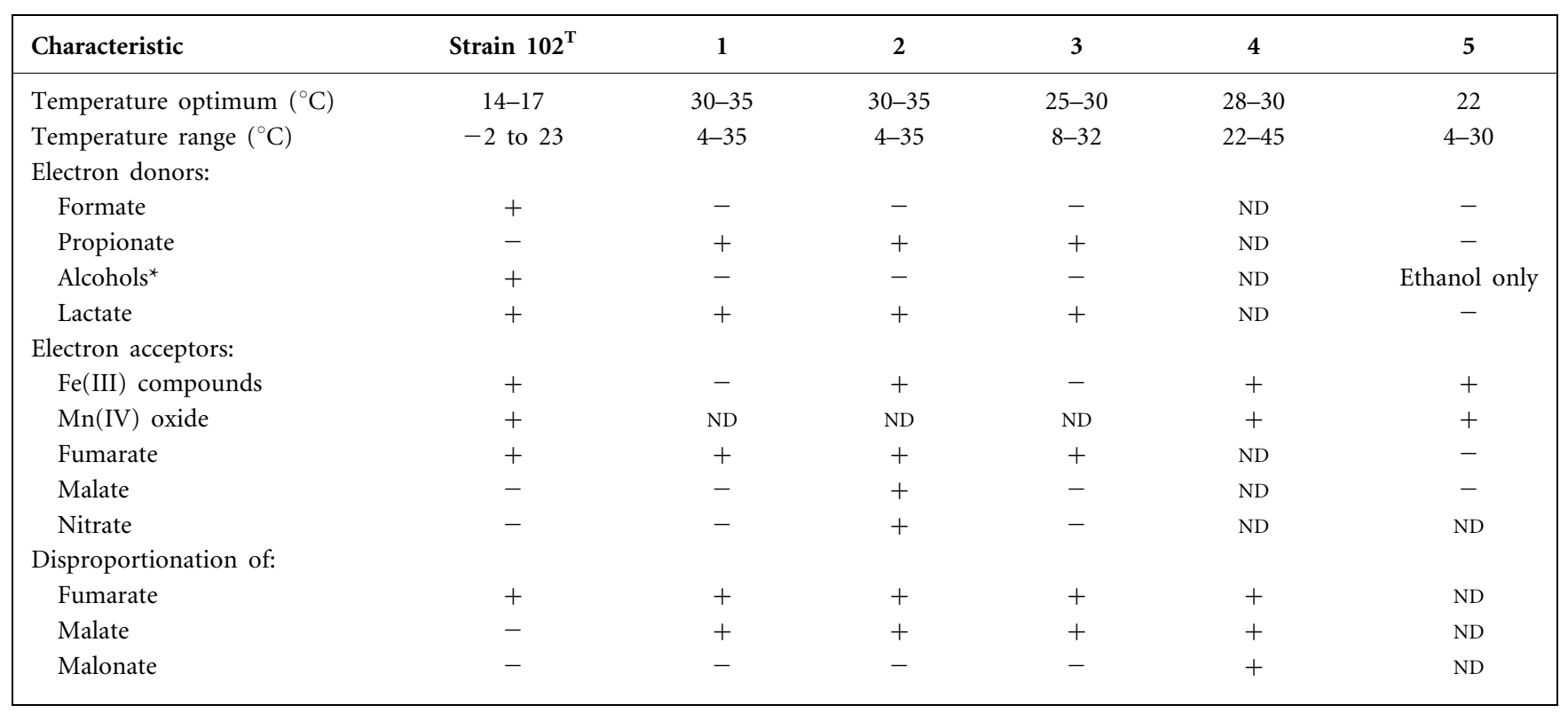

${ }^{\star}$ Alcohols tested were ethanol, propanol and butanol.

ability to reduce elemental sulfur and $\mathrm{Mn}(\mathrm{IV})$ and oxidize acetate, succinate and pyruvate, but differ in the usage of other substrates (Table 3).

The in situ abundance of members of the family Geobacteraceae had been demonstrated for temperate as well as permanently cold marine sediments of the Arctic and Antarctica, as several sequences closely related to strains of the Geobacteraceae had been found in 16S rRNA clone libraries of these sediments (Ravenschlag et al., 1999; Bowman \& McCuaig, 2003; Purdy et al., 2003; Mußmann et al., 2005). The isolation of strains $102^{\mathrm{T}}$ and $112^{\mathrm{T}}$ from marine sediments from Svalbard suggests that this group of bacteria is present in diverse freshwater and marine environments. Yet, the significance and in situ activity of the sulfur-/ferric iron-reducing members of the Geobacteraceae remains unclear for most habitats. As reviewed by Thamdrup (2000), ferric iron reduction is the second most important anaerobic respiration pathway in a wide range of habitats. In Arctic marine sediments of Svalbard, ferric iron reduction accounted for $0-26 \%$ of the total carbon respiration (Kostka et al., 1999). Marine surface sediments that have a zone of reactive iron and manganese as well as accumulation of elemental sulfur provide optimal conditions for bacteria able to reduce these compounds, such as the strains described here. Such a sediment setting was, for example, described on the Danish coast, where the concentration of sulfur was highest in the zone of iron/ manganese reduction (Sørensen \& Jørgensen, 1987), due to the rapid reaction of $\mathrm{H}_{2} \mathrm{~S}$ with $\mathrm{Mn}$ (IV) or $\mathrm{Fe}$ (III) to form elemental sulfur.

Possible substrates for Fe(III)-reducing bacteria are common fermentation products such as volatile short-chain fatty acids and hydrogen. Strains $112^{\mathrm{T}}$ and $102^{\mathrm{T}}$ oxidized important fermentation products such as acetate, lactate, formate or hydrogen concomitant with the reduction of $\mathrm{Fe}(\mathrm{III})$. Acetate is an important substrate for sulfatereducing bacteria in temperate as well as Arctic marine sediments (e.g. Sørensen et al., 1981; Finke, 2003). Turnover rates in Arctic fjord sediments were highest for acetate, followed by lactate and propionate (Finke, 2003).

Psychrophilic sulfate-reducing bacteria isolated from Svalbard sediments showed constant growth yields between $-2{ }^{\circ} \mathrm{C}$ and their optimum growth temperature (Knoblauch \& Jørgensen, 1999). Among the Fe(III)-reducing bacteria, psychrophiles of the genus Shewanella have been isolated from the Antarctic, the Alboran Sea and deep-sea sediments of the Pacific Ocean, including Shewanella frigidimarina, Shewanella gelidimarina, Shewanella woodyi and Shewanella violacea (Bowman et al., 1997; Makemson et al., 1997; Nogi et al., 1998). The strains isolated by Fe(III) reduction in the present study grew at in situ temperatures just above the freezing point of sea water and were accordingly well adapted to the permanently low temperatures of the Arctic Ocean. 
Recently, the first psychrophilic and psychrotolerant species within the family Geobacteraceae have been isolated, Geopsychrobacter electrodiphilus and Geobacter psychrophilus (Holmes et al., 2004b; Nevin et al., 2005). Our isolates extend the group of psychrophiles within the Geobacteraceae.

In summary, the isolated strains were well suited to life in anoxic, permanently cold sediments of Svalbard. The abundance and diversity of $\mathrm{Fe}(\mathrm{III})$ - and sulfur-reducing bacteria in this environment have, however, not been investigated. More studies on the microbial communities and their in situ activities are needed to understand fully the importance of sulfur and $\mathrm{Fe}(\mathrm{III})$ reduction in marine sediments.

\section{Description of Desulfuromonas svalbardensis sp. nov.}

Desulfuromonas svalbardensis (sval.bard.en'sis. N.L. fem. adj. svalbardensis from Svalbard, a group of islands in the northern Barents Sea, from where the type strain was isolated).

Cells are rod-shaped, $0 \cdot 7 \times 2 \cdot 5-3 \mu \mathrm{m}$, motile by peritrichous flagella. Gram-negative, strictly anaerobic and chemoorganotrophic. Biotin is required for growth. Grows by oxidation of acetate, propionate, ethanol, propanol, butanol, choline chloride or pyruvate with concomitant reduction of $\mathrm{Fe}(\mathrm{III})$. $\mathrm{Fe}$ (III) compounds, manganese oxide, elemental sulfur and fumarate serve as electron acceptors. Disproportionation of fumarate is observed. The $\mathrm{pH}$ range for growth is $\mathrm{pH} 6 \cdot 5-7 \cdot 5$; optimum $\mathrm{pH}$ is $7 \cdot 3$. Psychrophilic, with an optimum growth temperature of $14^{\circ} \mathrm{C}$ and a temperature range for growth of -2 to $20^{\circ} \mathrm{C}$. The DNA $\mathrm{G}+\mathrm{C}$ content of the type strain is $50 \cdot 1 \mathrm{~mol} \%$.

The type strain, strain $112^{\mathrm{T}}\left(=\mathrm{DSM} 16958^{\mathrm{T}}=\mathrm{JCM} 12927^{\mathrm{T}}\right)$, was isolated from a permanently cold fjord sediment of the west coast of Svalbard.

\section{Description of Desulfuromusa ferrireducens sp. nov.}

Desulfuromusa ferrireducens [fer.ri.re.du'cens. L. n. ferrum iron; L. part. adj. reducens leading back, bringing back and, in chemistry, converting to a reduced oxidation state; N.L. part. adj. ferrireducens reducing $\mathrm{Fe}(\mathrm{III})$ to $\mathrm{Fe}(\mathrm{II})]$.

Cells are rod-shaped, $0 \cdot 7-1 \times 3-5 \mu \mathrm{m}$, motile by monopolar lophotrichous flagella. Gram-negative, strictly anaerobic and chemo-organotrophic. No vitamins are required for growth. Oxidizes acetate, lactate, succinate, fumarate, pyruvate, proline, ethanol, propanol, butanol, formate or $\mathrm{H}_{2}$ with the reduction of $\mathrm{Fe}(\mathrm{III})$. Fe(III) compounds, elemental sulfur, manganese oxide and fumarate serve as electron acceptors. Disproportionation of fumarate is observed. The $\mathrm{pH}$ range for growth is $\mathrm{pH} 6 \cdot 5-7 \cdot 9$; optimum is $\mathrm{pH} 7 \cdot 0-7 \cdot 3$. Psychrophilic, with an optimum growth temperature of $14-17^{\circ} \mathrm{C}$ and a temperature range for growth of -2 to $23^{\circ} \mathrm{C}$. The DNA G + C content of the type strain is $52 \cdot 3 \mathrm{~mol} \%$.

The type strain, strain $102^{\mathrm{T}}\left(=\mathrm{DSM} 16956^{\mathrm{T}}=\mathrm{JCM} 12926^{\mathrm{T}}\right)$, was isolated from a permanently cold fjord sediment of the west coast of Svalbard.

\section{Acknowledgements}

We thank Flynn Picardal for the enjoyable introduction into the isolation of Fe-reducing bacteria and Christian Knoblauch for help with isolation of psychrophilic bacteria. Anke Toltz at the University of Bremen helped with the electron micrographs. Thanks to Stig Henningsen and John Mortensen for sampling on R/V Fram and to the Svalbard team 2001 for the exciting trip. We thank the Koldewey Station of the Alfred-Wegener-Institute for providing laboratory space. We thank two anonymous referees and the editor Professor Peter Kämpfer for useful comments. This research was supported by the Max Planck Society.

\section{References}

Bowman, J. P. \& McCuaig, R. D. (2003). Biodiversity, community structural shifts, and biogeography of prokaryotes within Antarctic continental shelf sediment. Appl Environ Microbiol 69, 2463-2483.

Bowman, J. P., McCammon, S. A., Nichols, D. S., Skerratt, J. H., Rea, S. M., Nichols, P. D. \& McMeekin, T. A. (1997). Shewanella gelidimarina sp. nov. and Shewanella frigidimarina sp. nov., novel Antarctic species with the ability to produce eicosapentaenoic acid $(20: 5 \omega 3)$ and grow anaerobically by dissimilatory $\mathrm{Fe}(\mathrm{III})$ reduction. Int $J$ Syst Bacteriol 47, 1040-1047.

Buchholz-Cleven, B. E. E., Rattunde, B. \& Straub, K. L. (1997). Screening for genetic diversity of isolates of anaerobic $\mathrm{Fe}$ (II)oxidizing bacteria using DGGE and whole-cell hybridization. Syst Appl Microbiol 20, 301-309.

Coates, J. D., Lonergan, D. J., Phillips, E. J. P., Jenter, H. \& Lovley, D. R. (1995). Desulfuromonas palmitatis sp. nov., a marine dissimilatory $\mathrm{Fe}$ (III) reducer that can oxidize long-chain fatty acids. Arch Microbiol 164, 406-413.

Cord-Ruwisch, R., Lovley, D. R. \& Schink, B. (1998). Growth of Geobacter sulfurreducens with acetate in syntrophic cooperation with hydrogen-oxidizing anaerobic partners. Appl Environ Microbiol 64, 2232-2236.

Dehning, I. \& Schink, B. (1989). Malonomonas rubra gen. nov., sp. nov., a microaerotolerant anaerobic bacterium growing by decarboxylation of malonate. Arch Microbiol 151, 427-433.

Elvert, M., Boetius, A., Knittel, K. \& Jørgensen, B. B. (2003). Characterization of specific membrane fatty acids as chemotaxonomic markers for sulfate-reducing bacteria involved in anaerobic oxidation of methane. Geomicrobiol J 20, 403-419.

Finke, N. (2003). The role of volatile fatty acids and hydrogen in the degradation of organic matter in marine sediments. $\mathrm{PhD}$ thesis, University of Bremen, Germany.

Finster, K. \& Bak, F. (1993). Complete oxidation of propionate, valerate, succinate, and other organic compounds by newly isolated types of marine, anaerobic, mesophilic, gram-negative, sulfurreducing eubacteria. Appl Environ Microbiol 59, 1452-1460.

Finster, K., Bak, F. \& Pfennig, N. (1994). Desulfuromonas acetexigens sp. nov., a dissimilatory sulfur-reducing eubacterium from anoxic freshwater sediments. Arch Microbiol 161, 328-332.

Finster, K., Coates, J. D., Liesack, W. \& Pfennig, N. (1997). Desulfuromonas thiophila sp. nov., a new obligately sulfur-reducing 
bacterium from anoxic freshwater sediment. Int J Syst Bacteriol 47, 754-758.

Holmes, D. E., Nevin, K. P. \& Lovley, D. R. (2004a). Comparison of $16 \mathrm{~S}$ rRNA, nifD, recA, gyrB, rpoB and fusA genes within the family Geobacteraceae fam. nov. Int J Syst Evol Microbiol 54, 1591-1599.

Holmes, D. E., Nicoll, J. S., Bond, D. R. \& Lovley, D. R. (2004b). Potential role of a novel psychrotolerant member of the family Geobacteraceae, Geopsychrobacter electrodiphilus gen. nov., sp. nov., in electricity production by a marine sediment fuel cell. Appl Environ Microbiol 70, 6023-6030.

Isaksen, M. F. \& Teske, A. (1996). Desulforhopalus vacuolatus gen. nov., sp. nov., a new moderately psychrophilic sulfate-reducing bacterium with gas vacuoles isolated from a temperate estuary. Arch Microbiol 166, 160-168.

Knoblauch, C. \& Jørgensen, B. B. (1999). Effect of temperature on sulphate reduction, growth rate and growth yield in five psychrophilic sulphate-reducing bacteria from Arctic sediments. Environ Microbiol 1, 457-467.

Kolb, S., Seelinger, S., Springer, N., Ludwig, W. \& Schink, B. (1998). The fermenting bacterium Malonomonas rubra is phylogenetically related to sulfur-reducing bacteria and contains a c-type cytochrome similar to those of sulfur and sulfate reducers. Syst Appl Microbiol 21, 340-345.

Kostka, J. E., Thamdrup, B., Glud, R. N. \& Canfield, D. E. (1999). Rates and pathways of carbon oxidation in permanently cold Arctic sediments. Mar Ecol Prog Ser 180, 7-21.

Krumholz, L. R. (1997). Desulfuromonas chloroethenica sp. nov. uses tetrachloroethylene and trichloroethylene as electron acceptors. Int J Syst Bacteriol 47, 1262-1263.

Krumholz, L. R., Sharp, R. \& Fishbain, S. S. (1996). A freshwater anaerobe coupling acetate oxidation to tetrachloroethylene dehalogenation. Appl Environ Microbiol 62, 4108-4113.

Liesack, W. \& Finster, K. (1994). Phylogenetic analysis of five strains of gram-negative, obligately anaerobic, sulfur-reducing bacteria and description of Desulfuromusa gen. nov., including Desulfuromusa kysingii sp. nov., Desulfuromusa bakii sp. nov., and Desulfuromusa succinoxidans sp. nov. Int J Syst Bacteriol 44, 753-758.

Lonergan, D. J., Jenter, H. L., Coates, J. D., Phillips, E. J. P., Schmidt, T. M. \& Lovley, D. R. (1996). Phylogenetic analysis of dissimilatory $\mathrm{Fe}(\mathrm{III})$-reducing bacteria. J Bacteriol 178, 2402-2408.

Lovley, D. (2000). Dissimilatory Fe(III)- and Mn(IV)-reducing prokaryotes. In The Prokaryotes. An Evolving Electronic Resource for the Microbiological Community. Edited by M. Dworkin, S. Falkow, E. Rosenberg, K. H. Schleifer \& E. Stackebrandt. http://141.150.157. 117:8080/prokPUB/index.htm

Lovley, D. R., Giovannoni, S. J., White, D. C., Champine, J. E., Phillips, E. J. P., Gorby, Y. A. \& Goodwin, S. (1993). Geobacter metallireducens gen. nov. sp. nov, a microorganism capable of coupling the complete oxidation of organic compounds to the reduction of iron and other metals. Arch Microbiol 159, 336-344.

Ludwig, W., Strunk, O., Westram, R. \& 29 other authors (2004). ARB: a software environment for sequence data. Nucleic Acids Res 32, 1363-1371.

Makemson, J. C., Fulayfil, N. R., Landry, W., van Ert, L. M., Wimpee, C. F., Widder, E. A. \& Case, J. F. (1997). Shewanella woodyi sp. nov., an exclusively respiratory luminous bacterium isolated from the Alboran Sea. Int J Syst Bacteriol 47, 1034-1039.
Mußmann, M., Ishii, K., Rabus, R. \& Amann, R. (2005). Diversity and vertical distribution of cultured and uncultured Deltaproteobacteria in an intertidal mud flat of the Wadden Sea. Environ Microbiol 7, 405-418.

Nevin, K. P., Holmes, D. E., Woodard, T. L., Hinlein, E. S., Ostendorf, D. W. \& Lovley, D. R. (2005). Geobacter bemidjiensis sp. nov. and Geobacter psychrophilus sp. nov., two novel Fe(III)-reducing subsurface isolates. Int J Syst Evol Microbiol 55, 1667-1674.

Nogi, Y., Kato, C. \& Horikoshi, K. (1998). Taxonomic studies of deep-sea barophilic Shewanella strains and description of Shewanella violacea sp. nov. Arch Microbiol 170, 331-338.

Pfennig, N. \& Biebl, H. (1976). Desulfuromonas acetoxidans gen. nov. and sp. nov., a new anaerobic, sulfur-reducing, acetate-oxidizing bacterium. Arch Microbiol 110, 3-12.

Purdy, K. J., Nedwell, D. B. \& Embley, T. M. (2003). Analysis of sulfate-reducing bacterial and methanogenic archaeal populations in contrasting Antarctic sediments. Appl Environ Microbiol 69, 3181-3191.

Ravenschlag, K., Sahm, K., Pernthaler, J. \& Amann, R. (1999). High bacterial diversity in permanently cold marine sediments. Appl Environ Microbiol 65, 3982-3989.

Roden, E. E. \& Lovley, D. R. (1993). Dissimilatory Fe(III) reduction by the marine microorganism Desulfuromonas acetoxidans. Appl Environ Microbiol 59, 734-742.

Sagemann, J., Jørgensen, B. B. \& Greef, O. (1998). Temperature dependence and rates of sulfate reduction in cold sediments of Svalbard, Arctic Ocean. Geomicrobiol J 15, 85-100.

Schink, B. (1984). Fermentation of 2,3-butanediol by Pelobacter carbinolicus sp. nov. and Pelobacter propionicus sp. nov., and evidence for propionate formation from $\mathrm{C}_{2}$ compounds. Arch Microbiol 137, 33-41.

Schink, B. \& Pfennig, N. (1982). Fermentation of trihydroxybenzenes by Pelobacter acidigallici gen. nov. sp. nov., a new strictly anaerobic, non-spore-forming bacterium. Arch Microbiol 133, 195-201.

Schink, B. \& Stieb, M. (1983). Fermentative degradation of polyethylene glycol by a strictly anaerobic, gram-negative, nonsporeforming bacterium, Pelobacter venetianus sp. nov. Appl Environ Microbiol 45, 1905-1913.

Sørensen, J. \& Jørgensen, B. B. (1987). Early diagenesis in sediments from Danish coastal waters: microbial activity and MnFe-S geochemistry. Geochim Cosmochim Acta 51, 1583-1590.

Sørensen, J., Christensen, D. \& Jørgensen, B. B. (1981). Volatile fatty acids and hydrogen as substrates for sulfate-reducing bacteria in anaerobic marine sediment. Appl Environ Microbiol 42, 5-11.

Stookey, L. L. (1970). Ferrozine - a new spectrophotometric reagent for iron. Anal Chem 42, 779-781.

Sung, Y., Ritalahti, K. M., Sanford, R. A., Urbance, J. W., Flynn, S. J., Tiedje, J. M. \& Löffler, F. E. (2003). Characterization of two tetrachloroethene-reducing, acetate-oxidizing anaerobic bacteria and their description as Desulfuromonas michiganensis sp. nov. Appl Environ Microbiol 69, 2964-2974.

Thamdrup, B. (2000). Bacterial manganese and iron reduction in aquatic sediments. Adv Microb Ecol 16, 41-84.

Widdel, F. \& Bak, F. (1992). Gram-negative mesophilic sulfatereducing bacteria. In The Prokaryotes, 2nd edn, pp. 3352-3378. Edited by A. Balows, H. G. Trüper, M. Dworkin, W. Harder \& K. H. Schleifer. Berlin: Springer. 